\title{
Phytochemical Analysis and Antidepressant Activity of Ixora coccinea Extracts in Experimental Models of Depression in Mice
}

\author{
Ixora coccinea Ekstrelerinin Fitokimyasal Analizi ve Sıçanlarda Depresyon \\ Deney Modeli Üzerindeki Antidepresan Aktivitesi
}

(D) Ajaykumar Rikhabchand SURANA ${ }^{1 *}$, (D) Rajendra Dayaram WAGH ${ }^{2}$

'S.M.B.T. College of Pharmacy, Dhamangaon, India

${ }^{2}$ A.R.A. College of Pharmacy, Dhule, India

\section{ABSTRACT}

Objectives: The present study aims to assess the antidepressant activity of Ixora coccinea extracts in mice and phytochemical analysis of the active extract by GC-MS.

Materials and Methods: After oral administration of extracts, tail suspension test (TST), force swim tests (FST), and open field tests (OFT) were performed to assess the antidepressant activity. GC-MS analysis of methanol extract of $I$. coccinea was performed to ascertain the chemical constituents in the bioactive extract.

Results: The methanol extract of $I$. coccinea at dose of 100 and $200 \mathrm{mg} / \mathrm{kg}$ body weight, p.o. significantly reduced the total duration of immobility in the TST as well as FST ( $p$ <0.01). I. coccinea extracts showed no significant changes in locomotor activity in OFT.

Conclusion: The methanol extract of I. coccinea possesses antidepressant-like properties in mice with no significant effect on locomotor activity in OFT.

Key words: Antidepressant activity, forced swim test, GC-MS, Ixora coccinea, open field test, tail suspension test

ÖZ

Amaç: Bu çalıșmada, Ixora coccinea ekstrelerinin sıçanlardaki antidepresan etkisi araștırılmış ve GC-MS tekniği kullanılarak aktif ekstrenin fitokimyasal analizi yapılmıştır.

Gereç ve Yöntemler: Ekstrelerin oral yolla uygulanmasının ardından, antidepresan etkinin değerlendirilmesi için kuyruktan asma testi (KAT), zorunlu yüzme testi (ZYT) ve açık alan testi (AAT) kullanılmıştır. Biyoaktif ekstredeki fitokimyasal bileşenleri aydınlatmak amacıyla I. coccinea metanollü ekstresi üzerinde GC-MS analizi yapılmıştır.

Bulgular: I. coccinea metanollü ekstresi 100 ve 200 mg/kg dozda, oral yolla uygulandığında, KAT ve ZYT testlerinde toplam hareketsizlik süresini anlamlı bir şekilde azaltmıştır ( $\mathrm{<}$ (0.01). I. coccinea ekstreleri AAT'de lokomotor aktivite üzerinde anlamlı derecede bir etki göstermemiştir.

Sonuç: I. coccinea metanollü ekstresi sıçanlarda, AAT'de anlamlı derecede lokomotor aktiviteye neden olmadan antidepresan-benzeri etkiye sahiptir. Anahtar kelimeler: Antidepresan aktivite, zorunlu yüzme testi, GC-MS, Ixora coccinea, açık alan testi, kuyruktan asma testi 


\section{INTRODUCTION}

Depression is a common illness. It was estimated that 350 million people are affected by this illness. Suicides can be the result of depression. It has been estimated that every year, approximately 1 million deaths occur due to depression. Depression is a heterogeneous disorder that often manifests with various symptoms at the psychological, behavioural, and physiologic levels.' Although treatment with commercially available antidepressant drugs is effective, a significant number of patients do not achieve continuous remission, despite intensive management, and only $60 \%$ of patients are responsive to currently available antidepressants. ${ }^{2}$ The most common adverse effects of these antidepressants include agitation, nausea, headache, sleeplessness or drowsiness, and sexual problems. The impulsive clinical response to antidepressant drugs and high susceptibility to adverse effects are major clinical problems ${ }^{3}$ thus, novel therapeutic agents are still needed to treat depression. Herbal treatment is another effective alternative to treat depression. The search for novel therapeutic plants that mitigate depressive disorders has been extensively explored over the past decade. ${ }^{4}$ Thus, developing an effective and safe chemical compound that originates from traditional medicinal herbal remedies may provide a method to minimize adverse effects and to shorten the entire process and reduce the cost of drug discovery compared with conventional chemistry-based drug discovery. ${ }^{5}$

Ixora coccinea Linn. (Rubiaceae) is a bushy, rounded shrub found in the subtropical region of Florida. The plant is grown as ornamental plant in India. It is commonly known as Rangon (Bengali), flame of wood (English), Bandhaka (Sanscrit). The flowers contain cycloartenol esters ${ }^{6}$ and have cytotoxic, hepatoprotective, ${ }^{7}$ antitumor, antimicrobial activity, ${ }^{8}$ and wound healing activity. ${ }^{9}$ The leaves contain triterpene ixorene, ${ }^{10}$ ixorapeptide I, ixorapeptide $\|,^{11}$ and quercitrin, ${ }^{12}$ and have cardioprotective, ${ }^{13}$ antinociceptive, ${ }^{14}$ antioxidant,,$^{15}$ antidiarrhoeal, ${ }^{16}$ antiasthmatic, ${ }^{17}$ hypoglycaemic, and hypolipidemic activity, ${ }^{18}$ and the roots show antioxidant activity. ${ }^{19}$

From a literature review, it appears that $I$. coccinea was used in folk medicine to treat various ailments such as in inflammatory conditions including sprains, eczema, contusions, and boils. The aim of the present study was to evaluate the antidepressant activity of $I$. coccinea stem extracts and perform gas chromatography-mass spectrometry (GC-MS) analysis of the active extract of $I$. coccinea.

\section{MATERIALS AND METHODS}

\section{Harvesting and authentication of plant material}

The I. coccinea stems were collected from the Dhule District, M.S., India, identified by Dr. S.G. Kotwal, HOD, Dept. of Botany, K.T.H.M. College, Nashik authenticated by Dr. Rao P.S.N., Scientist, B.S.I., Pune. The herbarium of the plant specimen has been deposited at B.S.I. Pune, the voucher specimen No. ARS-1 reference no: BSI/WC/Tech/2006/667.

\section{Chemicals and drugs}

Chloroform and methanol were obtained from Merck Ltd. (Mumbai, India). Gum acacia was from Sd fine-chem, (Mumbai, India). All chemicals and solvents used in the study were of analytical grade. Normal saline solution, imipramine, and fluoxetine were purchased from pharmacy shop.

\section{Extraction of plant material}

The stems of $I$. coccinea were air dried in the shade avoiding exposure to direct sunlight and were then pulverized in a grinder. The stem powder (\#60-80) material was successively extracted using chloroform and methanol with the continuous extraction method with the help of Soxhlet apparatus. After completion of extraction, the solvent was distilled out and the extract was dried through vacuum drying.

The extract suspension was prepared in $1 \%$ acacia solution by trituration. The fluoxetine or imipramine tablet powder equivalent was suspended in normal saline solution. All solutions were freshly prepared whenever required.

\section{Animals and treatment}

The animal experiments were performed in accordance with the guidelines for the care and use of laboratory animals, of the Committee for the Purpose of Control and Supervision of Experiments on Animals (CPCSEA), India and approved by the Institutional Animal Ethical Committee of S.M.B.T. College of Pharmacy, Dhamangaon, Nasik, (M.S.), India (Registration No.1329/ac/10/CPCSEA). Male albino mice (22-26 $\mathrm{g}$ and 3 to 4 months) were used for the study. All animals were maintained under controlled conditions of temperature $\left(22 \pm 2^{\circ} \mathrm{C}\right)$ and illumination (12 h light-dark cycle), with free access to food and water. Groups of six animals were structured and in order to reduce the influence of day variation all assays were conducted from 11 to $15 \mathrm{~h}$ and all assays were performed in a special noisefree room with controlled illumination.

The mice were divided into six groups $(n=6)$ and received the following oral doses for 7 days:

Group I: Vehicle treated group - physiologic saline solution,

Group II: Test - Suspension of chloroform extract of I. coccinea in $1 \%$ acacia solution (100 $\mathrm{mg} / \mathrm{kg}$ body weight per day),

Group III: Test - Suspension of chloroform extract of I. coccinea in $1 \%$ acacia solution ( $200 \mathrm{mg} / \mathrm{kg}$ body weight per day),

Group IV: Test - Suspension of methanol extract of I. coccinea in $1 \%$ acacia solution (100 mg/kg body weight per day),

Group V: Test - Suspension of methanol extract of $I$. coccinea in $1 \%$ acacia solution ( $200 \mathrm{mg} / \mathrm{kg}$ body weight per day),

Group VI: Positive control - fluoxetine or imipramine $(10 \mathrm{mg} / \mathrm{kg}$ body weight per day).

\section{Acute toxicity studies}

The acute oral toxicity of the extracts of $I$. coccinea was tested using the up and down procedure as per the Organization for Economic Cooperation and Development test guidelines. Animals were dosed, one at a time, at $24 \mathrm{~h}$ intervals. Depending on the outcome, the dose for the next animals was adjusted up. 
For further doses, a dose progression factor of 3.2 was used. The next dose was administered according to the mortality of the animal. The dose was increased if the animal survived. After reaching $2000 \mathrm{mg} / \mathrm{kg}$ body weight dose, four additional animals were administered the same dose. ${ }^{20}$

\section{Assessment of antidepressant activity}

\section{Forced swim test (FST)}

The FST was performed according to the method described by Porsolt et al. ${ }^{21}$ with a minor modification. Mice were individually forced to swim in an open cylindrical container (diameter 14 $\mathrm{cm}$, height $20 \mathrm{~cm}$ ), with a depth of $15 \mathrm{~cm}$ of water at $25 \pm 2^{\circ} \mathrm{C}$. The experimental procedures were performed on days 4 and 7, 60 min after the administration of test components. Each mouse was judged to be immobile during $6 \mathrm{~min}$. Immobility time in the FST was measured when the animals ceased struggling and remained motionless while floating in the water. The water in the containers was changed after each trial. ${ }^{22}$

\section{Tail suspension test (TST)}

The TST was performed according to the method described by Rosa et al. ${ }^{23}$ Mice were suspended $50 \mathrm{~cm}$ above the table with the help of adhesive tape placed approximately $1 \mathrm{~cm}$ from the tip of the tail. The total duration of immobility during a 6-min period was scored manually. Immobility time in TST was measured when animals showed no limb or body movements, hung passively and completely motionless, except for movements caused by respiration. ${ }^{24}$

\section{Open-field test (OFT)}

The locomotor activity was assessed using an OFT according to the method described by Herrera-Ruiz et al. ${ }^{25}$ in order to detect any link between locomotor activities and antidepressant activity of the $I$. coccinea extracts. The OFT was performed on mice that received treatments, which were used to determine immobility time in FST/TST 60 min before being observed in the openfield. Animals were placed individually in a box $(30 \times 30 \times 15 \mathrm{~cm})$, with the floor divided into 9 equal squares. After habituation to the arena for $5 \mathrm{~min}$, the number of squares crossed with all paws, grooming, and rearing events were observed for $6 \mathrm{~min}$. The box was cleaned with $10 \%$ ethanol after each trial. ${ }^{26}$

\section{Phytochemical investigation of active extracts using GC-MS}

The GC-MS analysis of the methanol extract of I. coccinea was performed at SAIF Panjab University Chandigarh, India. The chemical composition of the extracts was determined using a Thermo Scientific TSQ 8000 GC-MS with a direct capillary interface fused with silica capillary column TG 5MS (30 m x $0.25 \mathrm{~mm}, 0.25 \mu \mathrm{m})$. The methanol extract of $/$. coccinea were injected with helium used as a carrier gas at constant rate 1 $\mathrm{mL} / \mathrm{min}$, in pulsed splitless mode. The solvent delay was $2 \mathrm{~min}$ and the injection size was $1 \mu \mathrm{L}$. The mass spectrophotometric detector was operated in electron impact ionization mode with an ionizing energy of $70 \mathrm{eV}$ and scanning from m/z 50-500. The $\mathrm{GC}$ temperature program started at $60^{\circ} \mathrm{C}$ then elevated to $280^{\circ} \mathrm{C}$ at a rate of $10^{\circ} \mathrm{C} / \mathrm{min}$, with a $10 \mathrm{~min}$ hold at $280^{\circ} \mathrm{C}$. The injector, ion source, and detector temperatures were set at $250^{\circ} \mathrm{C}, 230^{\circ} \mathrm{C}$, and $280^{\circ} \mathrm{C}$, respectively. ${ }^{27,28}$ The peaks separated in GC-MS were identified using National Institute of Standards and Technology mass spectral databases.

\section{Statistical analysis}

All experimental results are given as the mean \pm standard error of the mean. To compare the test and control groups, One-way analysis of variance (ANOVA), followed by Dunnett's test was performed. A value of $p<0.01$ was considered to be significant.

\section{RESULTS}

\section{Extraction}

Fresh $250 \mathrm{~g}$ of stems of $\mathrm{l}$. coccinea yielded $8 \mathrm{~g}$ (3.20\%) and $18.55 \mathrm{~g}(7.42 \%)$ of chloroform extract and methanol extract respectively.

\section{Acute toxicity studies}

Chloroform and methanol extract of $I$. coccinea showed neither behavioural changes nor mortality with an oral dose of 2000 $\mathrm{mg} / \mathrm{kg}$.

\section{Antidepressant activity}

The effects of I. coccinea extracts on the immobility time in the force swim test

The methanol extract of $I$. coccinea showed an antidepressant effect in the FST because it significantly reduced the immobility time compared with the vehicle treated group $(184.00 \pm 4.76$ sec.) (Figure 1). The immobility times of the methanol extract of $l$. coccinea and the chloroform extract of $l$. coccinea for doses of 100 and $200 \mathrm{mg} / \mathrm{kg} /$ day on the $7^{\text {th }}$ day were found as $138.00 \pm 6.763$ and $124.7 \pm 6.36 \mathrm{sec}$, and $172.70 \pm 6.259$ and $160.00 \pm 7.849 \mathrm{sec}$, respectively. The chloroform extract of $I$. coccinea did not reduce immobility time significantly. The group treated with fluoxetine showed good activity $(111.83 \pm 4.826 \mathrm{sec})$. No significant difference was observed in the immobility time of $l$. coccinea extracts on $4^{\text {th }}$ day and the $7^{\text {th }}$ day in the FST.

The effect of I. coccinea extracts on the immobility time in the TST

In the TST, the methanol extract of $I$. coccinea showed a significantly decreased immobility time compared with the

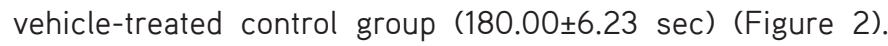

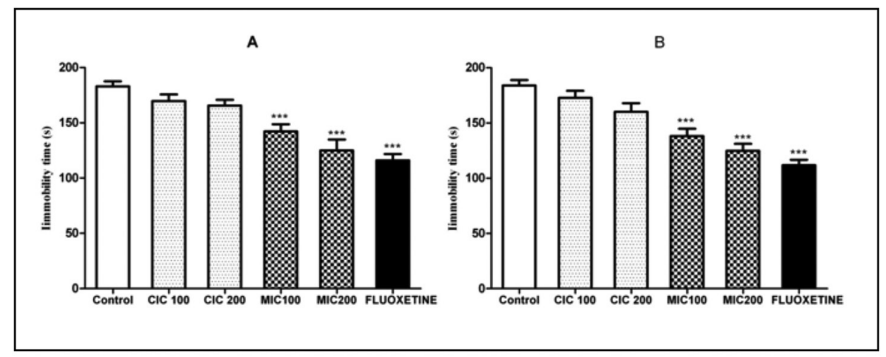

Figure 1. Effects of $I$. coccinea extracts (100 and $200 \mathrm{mg} / \mathrm{kg}$ ) and fluoxetine $(10 \mathrm{mg} / \mathrm{kg})$ on the immobility time in the forced swim test on $4^{\text {th }}$ day (A) and $7^{\text {th }}$ day $(B)$. The results are expressed as the mean \pm standard error of the mean, $n=6$ in each group. ${ }^{* * *} p<0.001$ VS the vehicle-treated control group. (CIC: Chloroform extract of I. coccinea, MIC: Methanol extract of I. coccinea) 


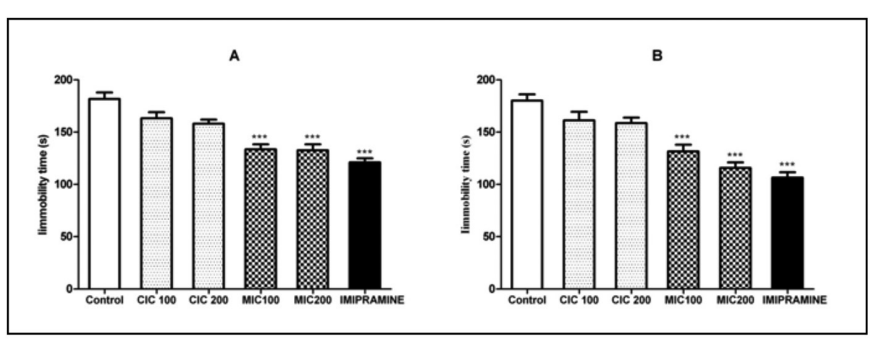

Figure 2. Effects of $I$. coccinea extracts ( 100 and $200 \mathrm{mg} / \mathrm{kg}$ ) and imipramine $(10 \mathrm{mg} / \mathrm{kg})$ on immobility time in the tail suspension test on $4^{\text {th }}$ day $(A)$ and $7^{\text {th }}$ day (B) in mice. The results are expressed as the mean \pm standard error of the mean, $n=6$ in each group. ${ }^{* * *} p<0.001 \mathrm{VS}$ the vehicle-treated control group. (CIC: Chloroform extract of I. coccinea, MIC: Methanol extract of $I$. coccinea)

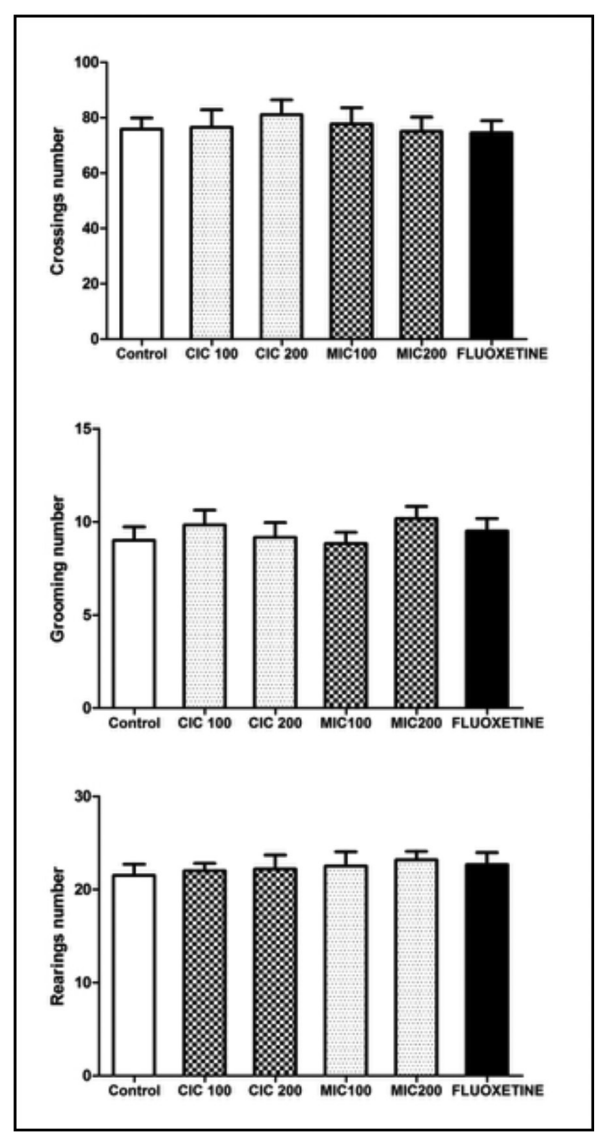

Figure 3. Effects of $l$. coccinea extracts ( 100 and $200 \mathrm{mg} / \mathrm{kg}$ ) and fluoxetine $(10 \mathrm{mg} / \mathrm{kg})$ after $7^{\text {th }}$ day administration on the number of crossings, and rearing and grooming activities in the open field test in mice. The results are expressed as the mean \pm standard error of the mean, $n=6$ in each group. (CIC: Chloroform extract of I. coccinea, MIC: Methanol extract of I. coccinea)

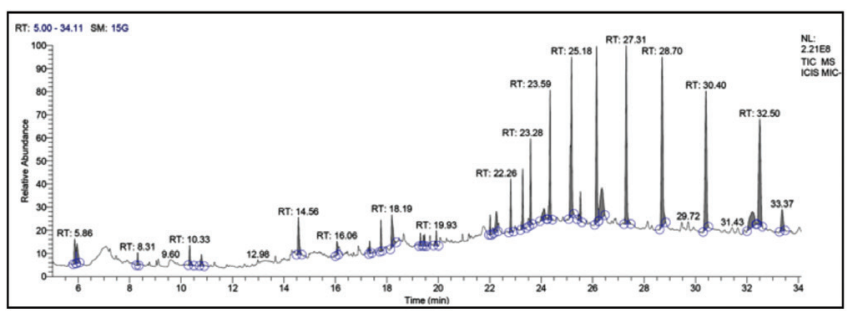

Figure 4. GC-MS chromatogram of methanol extract of I. coccinea
The mean immobility time of the methanol extract of $I$. coccinea treated group for 100 and $200 \mathrm{mg} / \mathrm{kg}$ dose was $131.50 \pm 6.515$ and $115.8 \pm 5.78 \mathrm{sec}$, respectively. The chloroform extract of $I$. coccinea did not show a significant effect on immobility time (161.3 8.044 and $158.50 \pm 5.476 \mathrm{sec})$. Imipramine, a nonselective reuptake inhibitor, which was used as positive control, significantly decreased the immobility time during the test session $(106.50 \pm 5.156 \mathrm{sec})$. No significant difference was observed in the immobility time of $l$. coccinea extracts on the $4^{\text {th }}$ and $7^{\text {th }}$ days in the TST.

The effects of I. coccinea extracts in the open field test

No significant differences were observed in the number of squares crossed, and rearing and grooming activities between the vehicle-treated group and the $I$. coccinea extracts-treated group, as well as positive control group (Figure 3 ).

\section{GC-MS analysis of pharmacologic active extract of I. coccinea}

The results obtained from GC-MS analysis lead to the identification of the phytoconstituents present in the methanol extract of I. coccinea. The GC-MS spectra (Figure 4) indicated the presence of 2-Methoxy-4-vinylphenol, 3,4-Dimethoxy-6methylpyrocatechol, 4-(3-hydroxy-1-propenyl)-2-methoxyPhenol, methyl ester of Hexadecanoic acid, n-Hexadecanoic acid, methyl ester of 9-Octadecenoic acid (Z), Methyl stearidonate, Heneicosane, 16,17- Epoxyandrostane, Triacontane, Diisooctyl phthalate, Tetracosane, Stigmast-4en-3-one, Squalene, and $\beta$-Sitosterol (Table 1).

\section{DISCUSSION}

Although I. coccinea has been used to treat nervous shock in traditional medicine, its specific neuropharmacologic activities have not yet been demonstrated. The FST and TST are the most common animal models used for screening antidepressant activity. In both tests, animals are placed in an inescapable situation and the decrease in immobility time indicates antidepressant-like activity. ${ }^{29,30}$ In the FST, mice are forced to swim in a restricted space from which they cannot escape and it assumes a characteristic behaviour of immobility. This behavior reflects a state of despair or lowered mood, which can be reduced by agents that are therapeutically active in human depression. The TST also induces a state of immobility in animals similar to that in the FST. Fluoxetine is a classic selective serotonin reuptake inhibitor (SSRI), it is bound at the primary site of pre-synaptic serotonin transporter with very high affinity, and it has higher serotonergic activity than other classic SSRIs. ${ }^{24}$ Imipramine prevents reuptake of noradrenaline and serotonin resulting in their increased availability in the synapse, and therefore, an increase in adrenergic and serotonergic neurotransmission. ${ }^{31}$

Psychostimulants, convulsants, and anticholinergics are able to increase locomotor activity in the OFT and give a false positive result in the TST and FST. ${ }^{32}$ Agents that show a hyperkinesis effect also produce false positive effects in the TST and FST by reducing the immobility time. ${ }^{33}$ Therefore, OFT was used to exclude these false effects that could be associated 
Table 1. Compounds present in the methanol extract of $I$. coccinea using GC-MS analysis

\begin{tabular}{|c|c|c|c|c|}
\hline Sr. no & Retention time & Name of compound & Mol. formula & Mol. weight \\
\hline 1. & 10.80 & 2-Methoxy-4-vinylphenol & $\mathrm{C}_{9} \mathrm{H}_{10} \mathrm{O}_{2}$ & 150.17 \\
\hline 2. & 14.56 & 3,4-Dimethoxy-6-methylpyrocatechol & $\mathrm{C}_{9} \mathrm{H}_{12} \mathrm{O}_{4}$ & 184.18 \\
\hline 3. & 16.06 & 4-(3-hydroxy-1-propenyl)-2-methoxy- Phenol & $\mathrm{C}_{10} \mathrm{H}_{12} \mathrm{O}_{3}$ & 180.20 \\
\hline 4. & 17.78 & Hexadecanoic acid, methyl ester & $\mathrm{C}_{17} \mathrm{H}_{34} \mathrm{O}_{2}$ & 270.45 \\
\hline 5. & 18.19 & n-Hexadecanoic acid & $\mathrm{C}_{16} \mathrm{H}_{32} \mathrm{O}_{2}$ & 256.42 \\
\hline 6. & 19.47 & 9-Octadecenoic acid ( $Z$ ), methyl ester & $\mathrm{C}_{19} \mathrm{H}_{36} \mathrm{O}_{2}$ & 296.48 \\
\hline 7. & 19.93 & Methyl stearidonate & $\mathrm{C}_{19} \mathrm{H}_{30} \mathrm{O}_{2}$ & 290.42 \\
\hline 8. & 22.02 & Heneicosane & $\mathrm{C}_{21} \mathrm{H}_{44}$ & 296.57 \\
\hline 9. & 22.26 & 16,17- Epoxyandrostane & $\mathrm{C}_{19} \mathrm{H}_{30} \mathrm{O}$ & 274.48 \\
\hline 10. & 22.82 & Triacontane & $\mathrm{C}_{30} \mathrm{H}_{62}$ & 422.81 \\
\hline 11. & 23.28 & Diisooctyl phthalate & $\mathrm{C}_{24} \mathrm{H}_{38} \mathrm{O}_{4}$ & 390.55 \\
\hline 12. & 23.59 & Tetracosane & $\mathrm{C}_{24} \mathrm{H}_{50}$ & 338.65 \\
\hline 13. & 24.11 & Stigmast-4-en-3-one & $\mathrm{C}_{29} \mathrm{H}_{48} \mathrm{O}$ & 412.69 \\
\hline 14. & 25.53 & Squalene & $\mathrm{C}_{30} \mathrm{H}_{50}$ & 410.71 \\
\hline 15. & 33.37 & $\beta$-Sitosterol & $\mathrm{C}_{29} \mathrm{H}_{50} \mathrm{O}$ & 414.70 \\
\hline
\end{tabular}

with psychostimulants, convulsants, and anticholinergics or hyperkinesis. ${ }^{2}$ The main difference between antidepressants and psychostimulants is that antidepressants would not increase locomotor activity. ${ }^{34}$ In addition, the finding suggested that the reduction of immobility time elicited by the methanol extract in the FST as well as in the TST was a specific result of its antidepressant mechanism. In the TST and FST, the methanol extract of $I$. coccinea decreased the immobility time, which was not due to any psychostimulant, anticholinergic or convulsant effect, or hyperkinesis activity.

The methanol extract of $I$. coccinea decreased immobility time, whereas the chloroform extract showed no effect in either the TST or the FST. The immobility in TST and FST, referred to as behavioral despair in animals, is believed to reproduce a condition similar to human depression. ${ }^{35}$

In the present study, the methanol extract of $I$. coccinea was analyzed using GC-MS. To date, no reports exists on the GC-MS analysis of $I$. coccinea stems. From GC-MS analyses, bioactive extracts that show significant antidepressant activity contain fatty acid or esters such as methyl ester of hexadecanoic acid, n-hexadecanoic acid, methyl ester of 9-Octadecenoic acid ( $Z$ ), Methyl stearidonate, Heneicosane, 16,17-Epoxyandrostane, Triacontane, Diisooctyl phthalate, Tetracosane; steroidals such as Stigmast-4-en-3-one, Squalene and $\beta$-Sitosterol; and phenolics such as 2-Methoxy-4-vinylphenol, 3,4-Dimethoxy6-methylpyrocatechol, 4-(3-hydroxy-1-propenyl)-2-methoxyPhenol. Phenolic compounds show good antidepressant activity; ${ }^{36,37}$ the methanol extract of I. coccinea showed prominent antidepressant activity due to these phytoconstituents.

\section{CONCLUSION}

The present study provides the first evidence that the methanol extract of $I$. coccinea has significant antidepressant activity in the TST and FST models of depression in mice. The antidepressant activity may due to the presence of phenolic components. Further research is required to elucidate the mechanism of its action.

\section{ACKNOWLEDGEMENTS}

Principal, S.M.B.T. College of Pharmacy, Dhamangaon, India for providing necessary facilities and SAIF Panjab University, Chandigarh, India for providing GC-MS analysis facility.

Conflict of Interest: No conflict of interest was declared by the authors.

\section{REFERENCES}

1. Dhingra S, Parle M. Herbal Remedies and Nutritional Supplements in the Treatment of Depression: A Systematic Review. Bull Clin Psychopharmacol. 2012;22:1.

2. Kwon S, Lee B, Kim M, Lee H, Park HJ, Hahm DH. Antidepressant-like effect of the methanolic extract from Bupleurum falcatum in the tail suspension test. Prog Neuro-Psychopharmacol Biol Psychiatry. 2010;34:265-270.

3. Ferguson JM. SSRI Antidepressant Medications: Adverse Effects and Tolerability. Prim Care Companion J Clin Psychiatry. 2001;3:22-27.

4. Lavretsky $\mathrm{H}$. Complementary and alternative medicine use for treatment and prevention of late-life mood and cognitive disorders. Aging Health. 2009;5:61-78.

5. Qureshi NA, Al-Bedah AM. Mood disorders and complementary and alternative medicine: a literature review. Neuropsychiatr Dis Treat. 2013;9:639-658. 
6. Ragasa CY, Tiu F, Rideout JA. New cycloartenol esters from Ixora coccinea. Nat Prod Res. 2004;18:319-323.

7. Shyamal S, Latha PG, Suja SR, Shine VJ, Anuja GI, Sini S, Pradeep S, Shikha P, Rajasekharan S. Hepatoprotective effect of three herbal extracts on aflatoxin B1-intoxicated rat liver. Singapore Med J. 2010;51:326-331.

8. Philomina NS, Kumar SP. Antimicrobial activity of Ixora coccinea flowers. Asian J Microbiol Biotechnol Environ Sci. 2011;13:605-607.

9. Nayak BS, Udupa AL, Udupa SL. Effect of Ixora coccinea flowers on dead space wound healing in rats. Fitoterapia. 1999;70:233-236.

10. Ikram A, Versiani MA, Shamshad S, Salman, Ahmed K, Syed TA, Faizi S. Ixorene, a New Dammarane Triterpene from the Leaves of Ixora. coccinea Linn. Rec Nat Prod. 2013;7:302-306.

11. Lee CL, Liao YC, Hwang TL, Wu CC, Chang FR, Wu YC. Ixorapeptide I and ixorapeptide II, bioactive peptides isolated from Ixora. Coccinea. Bioorg Med Chem Lett. 2010;20:7354-7357.

12. Bose S, Maji S, Chakraborty P. Quercitrin from Ixora coccinea Leaves and its Anti-oxidant Activity. J Pharm Sci Tech. 2013;2:72-74.

13. Momin FN, Kalai BR, Shikalgar TS, Naikwade NS. Cardioprotective effect of methanolic extract of Ixora coccinea Linn. leaves on doxorubicininduced cardiac toxicity in rats. Indian J Pharmacol. 2012;44:178-183.

14. Ratnasooriya WD, Deraniyagala SA, Galhena G, Liyanage SSP, Bathige SDNK, Jayakody JRAC. Anti-inflammatory Activity of the Aqueous Leaf Extract of Ixora coccinea. Pharm Biol. 2005;43:149-152.

15. Saha MR, Alam A, Akter R, Jahangir R. In vitro free radical scavenging activity of Ixora coccinea L. Bangladesh J Pharmacol. 2008;3:90-96.

16. Maniyar $Y$, Bhixavatimath $P$, Agashikar NV. Antidiarrheal activity of flowers of Ixora coccinea Linn. In rats. J Ayurveda Interg Med. 2010;1:287291.

17. Missebukpo A, Metowogo K, Agbonon A, Gadegbeku KE, Aklikokou K, Gbeassor M. Evaluation of Anti-asthmatic Activities of Ixora coccinea Linn (Rubiaceae). J Pharmacol Toxicol. 2011;6:559-570.

18. Maniyar $Y$, Bhixavatimath $P$. Evaluation of the hypoglycaemic and hypolipidaemic activities of the aqueous extract of the leaves of Ixora coccinea Linn in diabetic rats. J Clin Diagnostic Res. 2011;5:1381-1384.

19. Surana AR, Aher AN, Pal SC. In vitro and in vivo antioxidant activity of Ixora coccinea. J Med plants Res. 2013;7:3071-3075.

20. Blick DW, Murphy MR, Brown GC, Yochmowitz MG, Fanton JW, Hartgraves SL. Acute Behavioral Toxicity of Pyridostigmine or Soman in Primates. Toxicol Appl Pharmacol. 1994;126:311-318.

21. Porsolt RD, Bertin A, Jalfre M. Behavioral despair in mice: a primary screening test for antidepressants. Arch Int Pharmacodyn Ther. 1977;229:327-336.

22. Liu J, Qiao W, Yang Y, Ren L, Sun Y, Wang S. Antidepressant-like effect of the ethanolic extract from Suanzaorenhehuan Formula in mice models of depression. J Ethnopharmacol. 2012;141:257-264.

23. Rosa AO, Kaster MP, Binfaré RW, Morales S, Martín-Aparicio E, NavarroRico ML, Martinez A, Medina M, García AG, López MG, Rodrigues AL. Antidepressant-like effect of the novel thiadiazolidinone NP031115 in mice. Prog NeuroPsychopharmacology Biol Psychiatry. 2008;32:15491556.
24. Zeni AL, Zomkowski AD, Maraschin M, Tasca Cl, Rodrigues AL. Evidence of the involvement of the monoaminergic systems in the antidepressantlike effect of Aloysia gratissima. J Ethnopharmacol. 2013;148:914-920.

25. Herrera-Ruiz M, García-Beltrán Y, Mora S, Díaz-Véliz G, Viana GS, Tortoriello J, Ramirez G. Antidepressant and anxiolytic effects of hydroalcoholic extract from Salvia elegans. J Ethnopharmacol. 2006;107:53-58.

26. Wang Z, Gu J, Wang X, Xie K, Luan Q, Wan N, Zhang Q, Jiang H, Liu D. Antidepressant-like activity of resveratrol treatment in the forced swim test and tail suspension test in mice: The HPA axis, BDNF expression and phosphorylation of ERK. Pharmacol Biochem Behav. 2013;112:104110 .

27. Owaisi MA, Hadiwi NA, Khan SA. GC-MS analysis, determination of total phenolics, flavonoid content and free radical scavenging activities of various crude extracts of Moringa peregrina (Forssk.) Fiori leaves. Asian Pac J Trop Biomed. 2014;4:964-970.

28. Aal Abdel El, Haroon AM, Mofeed J. Successive solvent extraction and GC-MS analysis for the evaluation of the phytochemical constituents of the filamentous green alga Spirogyra longata. Egypt J Aquat Res. 2015;41:233-246.

29. Porsolt RD, Brossard G, Hautbois C, Roux S. Rodent Models of Depression: Forced Swimming and Tail Suspension Behavioral Despair Tests in Rats and Mice. Curr Protoc Neurosci. 2001.

30. Hurley LL, Akinfiresoye L, Kalejaiye O, Tizabi Y. Antidepressant effects of resveratrol in an animal model of depression. Behav Brain Res. 2014;268:1-7.

31. Colla AR, Machado DG, Bettio LE, Colla G, Magina MD, Brighente $I M$, Rodrigues AL. Involvement of monoaminergic systems in the antidepressant-like effect of Eugenia brasiliensis Lam. (Myrtaceae) in the tail suspension test in mice. J Ethnopharmacol. 2012;143:720-731.

32. Idayu NF, Hidayat MT, Moklas MA, Sharida F, Raudzah AR, Shamima AR, Apryani E. Antidepressant-like effect of mitragynine isolated from Mitragyna speciosa Korth in mice model of depression. Phytomedicine. 2011;18:402-407.

33. Freitas $A E$, Budni J, Lobato KR, Binfaré RW, Machado DG, Jacinto J, Veronezi PO, Pizzolatti MG, Rodrigues AL. Antidepressant-like action of the ethanolic extract from Tabebuia avellanedae in mice: Evidence for the involvement of the monoaminergic system. Prog NeuroPsychopharmacol Biol Psychiatry. 2010;34:335-343.

34. Borsini F, Meli A. Is the forced swimming test a suitable model for revealing antidepressant activity? Psychopharmacology (Berl). 1988;94:147-160.

35. Machado DG, Cunha MP, Neis VB, Balen GO, Colla A, Bettio LE, Oliveira A, Pazini FL, Dalmarco JB, Simionatto EL, Pizzolatti MG, Rodrigues AL. Antidepressant-like effects of fractions, essential oil, carnosol and betulinic acid isolated from Rosmarinus officinalis L. Food Chem. 2013;136:999-1005.

36. Messaoudi M, Bisson JF, Nejdi A, Rozan P, Javelot H. Antidepressantlike effects of a cocoa polyphenolic extract in Wistar-Unilever rats. Nutr Neurosci. 2008;11:269-276.

37. Lin S, Zhou Z, Zhang H, Yin W. Phenolic glycosides from the rhizomes of Cyperus rotundus and their antidepressant activity. J Korean Soc Appl Biol Chem. 2015;58:685-691. 